環境感染誌 Vol. 27 no. 3, 2012

〈原 著〉

擦式アルコール製剤の使用量および指先の擦り込みが除菌効果に与える影響の検討

東 知宏 ${ }^{1} \cdot$ 荒川 満枝 ${ }^{2} \cdot$ 池原 $\quad$ 弘展 ${ }^{1)} \cdot$ 森本美智子 ${ }^{1)} \cdot$ 鵜飼 和浩 1$)$

\title{
Effect of the Quantity of Alcohol-based Hand Rub and Fingertip Rubbing on Bacterial Elimination
}

Tomohiro Azuma ${ }^{1)}$, Mitsue Arakawa ${ }^{2)}$, Hironobu Ikehara ${ }^{1)}$, Michiko Morimoto ${ }^{1)}$ and Kazuhiro UGAi ${ }^{1)}$

1) College of Nursing Art \& Science, University of Hyogo, ${ }^{2)}$ Oita University Faculty of Medicine School of Nursing

(2011年 9 月 13 日 受付 $\cdot 2012$ 年 1 月 11 日 受理)

要旨

医療施設では擦式アルコール製剤を用いた手指消毒が推奨されているが，実際には製剤の使用量 が規定より少なく, 指先を擦り込んでいないと報告されている. そこで手指消毒時の指先擦り込み

の有無, 製剂使用量の違いが除菌効果に影響を与えるか検証した.

研究協力者は指先擦り込久実施群と指先擦り込久非実施群に分け，それぞれ製剂を規定の $3 \mathrm{~mL}$ と半量の $1.5 \mathrm{~mL}$ 使用し手指消毒を行った, 手指消毒前後の細菌をスタンプ法により指先, 指中 央, 手掌から採取し除菌効果の差を検証した.

指先擦り込久非実施群では, 指先の除菌率が指中央, 手掌と比較して有意に低かった(製剤使用 量 $3 \mathrm{~mL}, 1.5 \mathrm{~mL}$ ともに $\mathrm{p}<0.001)$. また, 指先擦り込久非実施群は, 実施群と比較して指先の指 数減少值が有意に低かった(製剤 $3 \mathrm{~mL}$ 使用時 $\mathrm{p}<0.01,1.5 \mathrm{~mL}$ 使用時 $\mathrm{p}<0.001$ ). 指先擦り込み非 実施群では, 製剤使用量が $1.5 \mathrm{~mL}$ の場合, $3 \mathrm{~mL}$ 使用した場合と比較して指先の指数減少值が有 意に低かった $(\mathrm{p}<0.01)$. 指中央, 手掌では製剤使用量の違い, 指先擦り込みの有無による除菌効 果の差はなかった。これらより, 手指消毒時に指先を擦り込まなければ除菌効果が低下することを 認識し, 指先擦り込みを意識して手指消毒を行う必要があるといえる.ささに, 製剤使用量を規定 の半量以下とすると, 除菌効果がより低下することを認識しておく必要がある.

Key words：擦式手指消毒，手指衛生，製剂使用量，除菌効果

はじめに

医療関連感染はカテーテル関連血流感染や手術部位感 染, 人工呼吸器関連肺炎など多岐にわたるが, 患者を感 染から守ることは医療者にとって重要な役割のひとつで ある．医療従事者は患者や環境表面から病原性微生物が 手を污染し ${ }^{1,2)}$, 他の患者や環境表面へ伝播している3). この人と人，環境表面と患者間という感染経路の遮断に おいて, 手指衛生は重要な役割を担っており, 適切な手 指衛生により医療関連感染を減少させることができ $ろ^{4 \sim 6)}$.

擦式アコール製剤を用いた手指消毒方法については， 2003 年度厚生労働科学研究「医療施設における院内感 染 (病院感染)の防止について」において「擦式アルコー

1)兵庫県立大学看護学部, 2) 大分大学医学部看護学科
ル製剂は 15 秒以内に乾燥しない程度の十分量 (約 3 $\mathrm{mL}$ )を使用し，アルコールが完全に揮発するまで両手 を擦り合せる必要がある」と記載されている7). また, 2002 年にアメリカ疾病予防管理センター Centers for Disease Control and Prevention: CDC)より公開された 「医療施設における手指衛生のためのガイドライン」に 掞いては，「擦式アルコール製剂で手指の污染除去をす る場合，製剤を片方の掌にとり，手の全体をくまなく両 手で手が乾くまで擦り込む，製剤の使用量は製造元の勧 告に従う」と勧告されている8). しかし，実際に行われ ている手指消毒内容には問題があると考えられる. 大須 賀は，洗浄剂と流水による手洗いと擦式手指消毒薬を使 用した手指消毒に打ける手指衛生手技を比較するため, 手指の部位別に洗浄，もしくは擦り込みを実施したか観 察し，その差を報告している9 ${ }^{9}$. その結果擦式手指消毒 
薬を使用した場合, 洗浄剂と流水を使用した手洗いと比 較し, 手掌と手掌側の指を除くすべての部位に抢ける擦 り込反の実施率が低く, 特に母指, 指先, 手首では $5 \%$ 以下であると報告している。 また， CDC による勧告や 厚生労働科学研究の記載に反して, 実際の医療の現場で は，擦式手指消毒剂を少量しかとらない医療從事者が多 いと考元られて抢り, 石渡ら ${ }^{10)}$ と前田ら ${ }^{11}$ は, 実際の 使用量が少ないことを報告している.

このように，臨床に抢ける手指消毒は指示されてい る方法とは異なっている。これまで, 製戍の使用量の 違いが除菌効果に与える影響の検証はなされてきた が10,12,13), これらの研究では臨床に打ける手指消毒手技 の現状は反映されておらず，手指消毒手技の違いや，手 指消毒手技の違いと製郕使用量の差の, 両方の違いによ る除菌効果への影響に関する研究は見られない。そこで 本研究では, 臨床で多用されるにもかかわらず, 擦り込 みが実施されていない指先に焦点を当て，指先に打ける 手指消毒時の除菌効果を, 指中央と手掌をコントロール 群として比較検討した. 本研究の目的は, 擦式手指消毒 時の指先擦り込久の有無と製剂使用量の差が，指先と指 中央, 手掌における除菌効果に及ぼす影響を検討し, 臨 床で行われている手指消毒の除菌効果を明らかにするこ とである.

\section{材料と方法}

\section{1. 研究協力者}

研究協力者は研究の趣旨を説明し同意の得られた, 手 荒れとアルコールアレルギーのない 18４2 歳の女性 24 名. 擦式アルコール製剤の持続効果による細菌数への影 響を考慮し, 研究に参加する前 24 時間以内にアルコー 儿製剂を使用した者は研究協力者から除いた。

\section{2. 実験期間}

2008 年 9 月 2009 年 8 月.

\section{3. 細菌採取方法}

擦式アルコール製剤はウエルパス゚(83\%エタノール, $0.2 \%$ 塩化ベンザルコニウム, 丸石製薬株式会社)を使用 した.

細菌の採取は, 手指消毒前後にスタンプ法を用いて指 先, 指中央, 手掌から行った. 指先の細菌は SCDLP 寒 天培地 (SCDLP 寒天培地「栄研」, 栄研化学) を使用し, 指中央, 手掌の細菌は SCDLP 寒天培地 (クリーンスタ

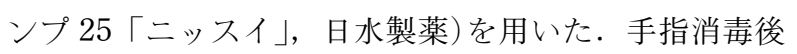
の細菌検查は, 肉眼的に消毒薬が乾燥したことを確認し てから行った。

指先の細菌検查は五指すべての指で行った。まず 1 $\mathrm{cm}^{2}$ の正方形のマーキングを行った台紙上に寒天培地を 設置し, 培地が破損しないように指先の腹側を 45 度の 状態でマーク内に接地し，その後爪部の細菌を採取する
ため指先を 90 度まで起こした。細菌検査は, 培養中に 寒天培地が破損することを考慮しおの抢の一指ずつ 3 回行った．指中央の細菌採取は第二～第四指の指腹中央 部から 1 回行った。手掌の細菌検査は手掌中央から 1 回行った.

細菌数は, 培養後に発生した細菌コロニー( colony forming units ; 以下 CFUs) を全数カウントした. 指先 の細菌コロニー数は, 3 回採取した結果のうち最も多い ものを採用し, 五指の総和を指先の細菌コロニ一数とし た.

\section{4. 手指消毒および細菌検査手順}

手指消毒手順は丸石製薬株式会社が提示している「ウ

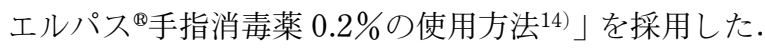

〈手指消毒手順〉

製剂の使用量が一定となるよう,ノズルは研究者がプ ッシュした．その後の手指消毒手順は以下の通りである.

1）製剂を手掌にとる.

2）指先に製剂を擦り込む.

3）手掌に製剤を擦り込む.

4）手背に製剂を擦り込む.

5）指間に製剂を擦り込む.

6）母指に製剂を擦り込む.

7）手首に製剂を擦り込む.

8）自然乾燥させる.

〈細菌検查手順〉

右手の細菌検査をした後, 左手に手袋を装着した状態 で手指消毒手順の2）の項目を除いた 1)から8）の手順で 手指消毒を行い, 右手の細菌検査をした。これを指先擦 り込反非実施群とする。 その後左手の手袋を外し，右手 に手袋を装着した後, 左手の細菌検查をした。その後手 指消毒手順 1) から 8)を行い，左手の細菌検査をした. これを指先擦り込み実施群とする.

製剂の使用量は製品規定の $3 \mathrm{~mL}$ と半量の $1.5 \mathrm{~mL}$ と し，それぞれに抢ける指先擦り込久非実施群と実施群か らデータを収集した。

\section{5. 統計処理}

指先，指中央，手掌それぞれにおおる，手指消毒時の 細菌コロニ一数の変化は, カウントした細菌コロニー数 を $\log 10$ で指数化し ( $\log$ CFUs), Wilcoxon 符号付順位 検定を用いて検証した. 各部位間の除菌効果の差は, 採 取面積が異なるため除菌率を使用し Mann-Whitney 検 定を行い検証した。指先，指中央，手掌それぞれに打け る, 指先擦り込久の有無や製剤使用量の違いによる除菌 効果への影響は, 指数減少值と手指消毒後に採取された 細菌コロニー数 ( $\log \mathrm{CFUs}$ )を用い, Mann-Whitney 検 定を行い検証した。

除菌率 $(\%)=\{($ 手指消毒前細菌コロニ一数 - 手指消毒 後細菌コロニー数) / 手指消毒前細菌コロ 


$$
\text { 二一数 }\} \times 100
$$

指数減少值 $(\log \mathrm{CFUs})=\log _{10}$ 手指消毒前細菌コロ ニ一数 $-\log _{10}$ 手指消毒後 細菌コロニー数

有意水準は $\mathrm{p}<0.05$ とした. 検定の計算には統計処理 ソフト「SPSS Statistics ver.19.0」を使用した。

\section{6. 倫理的配慮}

本研究は兵庫県立大学看護学部研究倫理委員会の審査 と承認を得た後に行った。

\section{結 果}

\section{1. 手指消毒前後の細菌コロニー数の比較}

指先，指中央，手掌すべての部位に打いて，擦式アル コール製剂の使用量，指先擦り込みの有無にかかわら ず，手指消毒後は手指消毒前よりも細菌コロニー数が有 意に減少していた（すべての部位で $\mathrm{p}<0.001)$.

\section{2. 手指消毒部位間の除菌効果の比較}

製剂使用量が $3 \mathrm{~mL}$ の場合，指先擦り込久非実施群の 指先に打ける除菌率は, 指中央, 手掌と比較し有意に劣 っていた（指中央，手掌ともに $\mathrm{p}<0.001$ )（表 1).

製剂使用量が $1.5 \mathrm{~mL}$ の場合，指先擦り込久非実施群 の指先に抢ける除菌率は，指中央，手掌と比較し有意に 劣っていた(指中央, 手掌ともに $\mathrm{p}<0.001$ ) (表 1). 一方 製剂使用量が $3 \mathrm{~mL}, 1.5 \mathrm{~mL}$ ともに，指先擦り込及実施 群では指先に抢ける除菌率と，指中央，手掌との間に差 がなかった(表 1)。

\section{3. 手指消毒部位別の除菌効果の比較}

部位別にみると，指先では製剂使用量が $3 \mathrm{~mL}$ の場合， $1.5 \mathrm{~mL}$ の場合ともに指先擦り込久非実施群の指数減少 值は，実施群と比較して有意に低かった(製剤使用量 3 $\mathrm{mL}, 1.5 \mathrm{~mL}$ ともに $\mathrm{p}<0.001$ )（図 1)。さらに，製剤使
用量が $3 \mathrm{~mL}$ の場合， $1.5 \mathrm{~mL}$ の場合ともに，指先擦り 込久非実施群は実施群と比較して除菌後に検出された細 菌コロニー数が有意に多かった(製剤使用量 $3 \mathrm{~mL} ： \mathrm{p}<$ 0.01, $1.5 \mathrm{~mL}: \mathrm{p}<0.001$ ) (表 2).

また，指先擦り込久非実施群では，製剤使用量が 3 $\mathrm{mL}$ の場合と比較し， $1.5 \mathrm{~mL}$ の場合手指消毒時の指数 減少值が有意に低かった $(\mathrm{p}<0.01)$ （図 1)。さらに，指 先擦り込み非実施群では，製剤使用量が $3 \mathrm{~mL}$ の場合と 比較し， $1.5 \mathrm{~mL}$ の場合は手指消毒後に採取される細菌 コロニー数が有意に多かった $(\mathrm{p}<0.05)$ (表 2$)$. 指先擦 り込久実施群では，製剤使用量の違いによる，手指消毒 時の指数減少值および手指消毒後に採取される細菌コロ ニー数の差はなかった.

一方，指中央，手掌では製剤使用量の差，指先擦り込

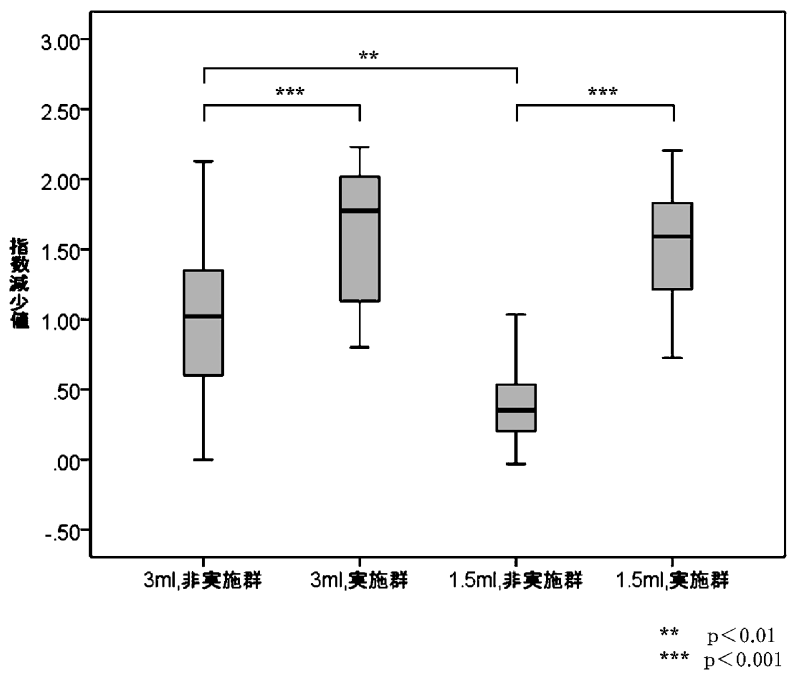

図 1 指先における指数減少値の比較

表 1 手指消毒部位ごとの除菌率

\begin{tabular}{|c|c|c|c|c|c|}
\hline & \multirow{2}{*}{ 製剂量 } & \multirow{2}{*}{ 部 位 } & 际 & \multicolumn{2}{|l|}{ (\%) } \\
\hline & & & Mean ( $\pm S D)$ & Median (IOR) & \\
\hline \multirow{6}{*}{$\begin{array}{c}\text { 指先擦り込み } \\
\text { 非実施群 }\end{array}$} & \multirow{3}{*}{$3 \mathrm{~mL}$} & 指先 $(N=24)$ & $80.0( \pm 25.7)$ & $90.4(76.0-97.5)$ & \multirow{3}{*}{$* * *$} \\
\hline & & 手掌 $(N=22)$ & $100.0( \pm 0.0)$ & $100.0(100.0-100.0)]^{* * *}$ & \\
\hline & & 指中央 $(N=22)$ & $100.0( \pm 0.0)$ & $100.0(100.0-100.0)$ & \\
\hline & \multirow{3}{*}{$1.5 \mathrm{~mL}$} & 指先 $(N=24)$ & $52.5( \pm 30.1)$ & $55.8(39.0-70.1)$ & \multirow{3}{*}{$* * *$} \\
\hline & & 手掌 $(N=24)$ & $89.7( \pm 22.3)$ & $100.0(92.2-100.0)]^{* * *}$ & \\
\hline & & 指中央 $(N=23)$ & $87.9( \pm 24.1)$ & $100.0(85.4-100.0)$ & \\
\hline \multirow{6}{*}{$\begin{array}{c}\text { 指先擦り込み } \\
\text { 実施群 }\end{array}$} & \multirow{3}{*}{$3 \mathrm{~mL}$} & 指先 $(N=24)$ & $96.5( \pm 5.3)$ & $100.0(93.3-100.0)$ & \\
\hline & & 手掌 (N = 22) & $96.6( \pm 11.0)$ & $100.0(100.0-100.0)$ & \\
\hline & & 指中央 $(N=22)$ & $93.2( \pm 23.4)$ & $100.0(100.0-100.0)$ & \\
\hline & \multirow{3}{*}{$1.5 \mathrm{~mL}$} & 指先 $(N=24)$ & $96.6( \pm 4.5)$ & $98.4(93.9-100.0)$ & \\
\hline & & 手掌 (N=23) & $96.9( \pm 5.7)$ & $100.0(96.1-100.0)$ & \\
\hline & & 指中央 $(N=23)$ & $91.9( \pm 21.5)$ & $100.0(92.7-100.0)$ & \\
\hline
\end{tabular}

$* * * p<0.001$ 
表 2 手指消毒後の細菌コロニー数 $(N=24)$

\begin{tabular}{|c|c|c|c|c|}
\hline \multirow{2}{*}{ 部位 } & \multirow{2}{*}{ 製剤量 } & \multirow{2}{*}{$\begin{array}{l}\text { 指先擦 } \\
\text { り込 }\end{array}$} & \multicolumn{2}{|c|}{ 細菌コロニー数 (logCFUs) } \\
\hline & & & Mean $( \pm S D)$ & Median (IQR) \\
\hline \multirow{4}{*}{ 指先 } & $3 \mathrm{~m}$ & 非実施群 & $0.95( \pm 0.77)$ & $0.90(0.23-1.68)-$ \\
\hline & $3 \mathrm{ml}$ & 実施群 & $0.29( \pm 0.50)$ & $0.00(0.00-0.38)-$ \\
\hline & & 非実施群 & $1.50( \pm 0.58)$ & $1.52(1.04-1.96)_{7} \rightarrow$ \\
\hline & & 実施群 & $0.45( \pm 0.52)$ & $0.15(0.00-0.88)\rfloor$ \\
\hline \multirow{4}{*}{ 中5 } & & 非実施群 & $0.00( \pm 0.00)$ & $0.00(0.00$ \\
\hline & 3 & 実施群 & $0.00( \pm 0.00)$ & $0.00(0$ \\
\hline & & 非実施群 & $0.11( \pm 0.34)$ & $0.00(0.00-0.00)$ \\
\hline & & 実施群 & $0.06( \pm 0.14)$ & $0.00(0.00-0.00)$ \\
\hline \multirow{4}{*}{ 手掌 } & & 非実施群 & $0.00( \pm 0.00)$ & $0.00(0.00-0.00)$ \\
\hline & $3 \mathrm{ML}$ & 実施群 & $0.04( \pm 0.13)$ & $0.00(0.00-0.00)$ \\
\hline & & 非害† & $0.11( \pm 0.27)$ & $0.00(0.00-0.00)$ \\
\hline & & 実施群 & $0.09( \pm 0.22)$ & $0.00(0.00-0.00)$ \\
\hline
\end{tabular}

$$
\begin{array}{rl}
* & p<0.05 \\
* * & p<0.01 \\
* * * & p<0.001
\end{array}
$$

みの有無の違いによる, 手指消毒時の指数減少值抢よび 手指消毒後に採取された細菌コロニ一数に差はなかった (表 2).

\section{考察}

本研究では, 指中央と手掌をコントロール群とし, 指 先に抢ける擦式アルコール製剤の使用量の違い, 指先擦 り込反の有無による除菌効果の差を検討した。その結 果, 指先擦り込及非実施時には製剂の使用量に関わら ず, 手指消毒時の指先の除菌効果は指中央, 手掌と比較 して低下していることが判明した。ささらに, 製剤使用量 を規定の半量である $1.5 \mathrm{~mL}$ にすると, 規定量を使用し 手指消毒を行った場合と比較し, 指先の除菌効果が低下 していることが明らかとなった．指先擦り込及非実施時 であっても，手指消毒を行う過程で製郕が指先に付着す るため，指先を除菌することができるが，指先の擦り込 みを行わないために指先に付着する製剤量が不十分です ぐに乾いてしまい, 除菌効果の発現が低下したと考えら れる，さらに，手指消毒に使用する製片量が少ない場合 には指先に付着する製剤量も減少するため, 指先擦り込 み非実施群における, 指先の除菌効果低下への影響が大 きくなったと考えられる.

指先擦り込及実施群では, 製剤の使用量に関わらず指 先, 指中央, 手掌間の除菌効果には差がなかった。この ことから, 製剂使用量が少ない場合であっても, まず指 先の擦り込みを行い，その後手全体に製剂を塗布するこ とにより, 指先に扔いても, 指中央や手掌と同程度の除 菌効果を得られることが判明した。
一方, 指中央と手掌は, 製剂使用量の違いと指先擦り 込みの有無による除菌効果への影響を受けなかった。こ れは指中央と手掌が製剂を手に取り 2 番目に擦り合わ せる部位であるため, たとえ規定の半量であっても製剂 が指中央と手掌全体に行き届くことにより, 製剂使用量 の違いと指先の擦り込反の有無による影響を受けなかっ たものと考える. 大須賀は，手掌の擦り合わせ実施率は 99.6\%であったと報告しており ${ }^{9)}$ ，実際の製剤使用量が 少ない臨床においても，指中央と手掌は推奨されている 手指消毒を行った場合と同等の除菌効果を得ているとい える.しかし，指先擦り达反の実施が $5 \%$ 以下であった という大須賀の研究9) や, 実際に使用されている擦式手 指消毒剤の量が規定よりも少ないという石渡ら 10 ) や前 田ら ${ }^{11)}$ の研究結果と, 本研究に抢ける, 手指消毒方法 の不備により指先に扔ける除菌効果が低下するという結 果から, 臨床でよく行われている手指消毒では, 指先に おける除菌効果が低下していると考えられる. Pittet ら の研究では, 医療従事者は日々のケア中, 特に患者への 直接接触, 呼吸器のケア, 体液の取扱いに抢いて患者の 細菌叢を獲得していることが示されており1)，Buresら の研究では, 医療従事者は医療現場にあるキーボードか ら病原性微生物を獲得していることが示されている2). そして, 患者への接触, 処置時に医療従事者は主に指先 を使用しており, キーボードを操作する際にも使用する のは指先である、そのため, 医療従事者がキーボードや 患者から獲得した病原性微生物を除菌し, 他の患者への 伝播を防ぐためには，多用される指先を確実に消毒する 必要がある。したがって, 擦式手指消毒では医療従事者 は手順通りに早い段階で，消毒部位として重要な指先を 確実に擦り込む必要があると言える。

石渡 ${ }^{10)}$ や Larson ら ${ }^{12)}$, Kampf ${ }^{13)}$ の研究では, 擦式 アルコール製剤の使用量が少ない場合，手指消毒による 除菌効果が低下することが示されている. 本研究では, 製剤使用量が少ない場合であっても指先の擦り込久を行 うことにより，指先，指中央，手掌では製片を規定量使 用した場合と同等の除菌効果が得られており, 石渡ら， Larson ら, Kampf の研究結果とは異なっている。その 理由として, 石渡らや Larson ら, Kampf の研究では, 除菌前後の細菌コロニーの検出にグローブジュース法を 用い, 手全体の細菌コロニ一数の変化を観察している. 一方, 本研究ではスタンプ法を用いて指先, 指中央, 手 掌に限定し細菌コロニ一数の変化を観察した. したがっ て, 石渡ら, Larson ら, Kampf の研究に扔いて, 製剂 使用量が少ないことにより除菌効果が有意に低下した原 因は, 指先, 指中央, 手掌以外の部位に抢ける除菌効果 の低下による影響であることが推測される，その原因と しては，擦式アルコール製剤を使用し手指消毒を行う 際, 指先, 指中央, 手掌の擦り込みは手指消毒手順の前 
半で実施され，その他の部位である指間，手背，手首の 擦り込みはその後に実施される。そのため製剤の使用量 が少ない場合であっても, 指先, 指中央, 手掌を擦り込 む段階では製剂が擦り込んだ部位に塗布されており有効 な除菌効果を発現するが, 指間, 手背, 手首を擦り込む 段階では塗布と揮発により製剤が減少しており，除菌効 果の低下を招くものと考えられる. 本研究では, 手指消 毒時の指先, 指中央, 手掌に扑除菌効果执よび, 部 位間の除菌効果の差を明らかにすることができたが，指 間や手背といった手指の異なる部位については検討する ことができなかったため, 今後検討が必要である。ま た, 本研究の協力者は女性だけであった. 女性と比較し 男性の手は大きい場合が多いため, 男性が手指消毒を行 う際に必要な製剂量も相対的に多くなることが推測され る. そのため, 男性を対象として本研究行った場合に は, 擦式アルコール製剤の使用量が少ないことによる影 響が大きくなる可能性があるため, 男性を対象とした検 証も必要と考える.

謝 辞 : 本研究を行うにあたりご協力いただきました皆様，お よびご指導いただきました兵庫県立大学坂下玲子教授に深謝い たします。

利益相反について : 利益相反はない.

\section{文献}

1) Pittet D, Dharan S, Touveneau S, Sauvan V, Perneger TV: Bacterial Contamination of the Hands of Hospital Staff During Routine Patient Care. Arch Intern Med 1999; 159: 821-6.

2) Bures S, Fishbain JT, Uyehara CFT, Parker JM, Berg BW: Computer keyboards and faucet handles as reservoirs of nosocomial pathogens in the intensive care unit. Am J Infect Control 2000; 28 (6) : 465-71.

3) Duckro AN, Blom WB, Lyle EA, Weinstein RA, Hayden MK: Transfer of vancomycin-resistant Enterococci via health care worker hands. Arch Intern Med 2005; 165: 302-7.

4) Pittet D, Hugonnet S, Harbarth S, Mourouga P, Sauvan V, Touveneau S, et al.: Effectiveness of a hospital-wide programme to improve compliance with hand hygiene. Lancet 2000; 356: 1307-12.

5) Larson EL, Early E, Cloonan P, Sugrue S, Parides M: An organaizational climate intervention associated with increased handwashing and decreased nosocomial infections. Behav Med 2000; 26(1): 14-22.

6) Grayson ML, Jarvie LJ, Martin R, Johnson PD, Jodoin ME, McMullan C, et al.: Significant reductions in methicillin-resistant Staphylococcus aureus bacteraemia and clinical isolates associated with a multisite, hand hygiene culture-change program and subsequent successful statewide roll-out. Med J Aust 2008; 188: 63340.

7) 大久保 憲: 平成 15 年度厚生労働科学研究費補助金 (厚生労働科学特別研究事業) 分担研究報告書 : 国, 自 治体を含めた院内感染対策全体の制度設計に関する緊 急特別研究.

http://www.mhlw.go.jp/topics/2005/02/dl/tp0202-1. pdf, accessed August 26, 2011.

8) Boyce J, Pittet D: Guideline for hand hygiene in healthcare settings. Recommendations of the healthcare infection control practices advisory committee and the HICPAC/SHEA/APIC/IDSA Hand hygiene task force. MMWR Recomm Rep 2002; 51: 1-44.

9）大須賀ゆか：擦式手指消毒法と流水下での手指衛生行 動の比較検討. 環境感染 2005; 20 (1): 13-8.

10）石渡 渚, 鈴木佳奈子, 松本春菜, 矢島慶子, 小野麻 里子, 土田沙織, 他 : 速乾性擦式消毒薬の消毒効果扝 よび日常的な使用法に関する検討. 環境感染誌 2009; 24(5): 319-23.

11）前田ひとみ, 深井喜代子：手洗い教育に関する研究 I 一基礎看護学実習に抢ける看護学生の手洗い.手指 衛生行動の実態から一. INFECT CONTROL 2005; 14(5): 478-83.

12) Larson EL, Eke PI, Wilder MP, Laughon BE: Quantity of Soap as a Variable in Handwashing. Infect Control 1987; 8(9): 371-5.

13) Kampf G: How effective are hand antiseptics for the postcontamination treatment of hands when used as recommended? Am J Infect Control 2008; 36 (5): 35660.

14）丸石製薬株式会社：ウエルパス手指消毒液 $0.2 \%$ の使 用法.

http://www.maruishi-pharm.co.jp/med/main_product/ wel/index.php, accessed August 26, 2011.

〔連絡先：=673-8588 兵庫県明石市北王子町 13 号 71 番 兵庫県立大学看護学部 東 知宏

E-mail: tomohiro_azuma@cnas.u-hyogo.ac.jp] 


\title{
Effect of the Quantity of Alcohol-based Hand Rub and Fingertip Rubbing on Bacterial Elimination
}

\author{
Tomohiro Azuma ${ }^{1)}$, Mitsue Arakawa ${ }^{2)}$, Hironobu Ikehara ${ }^{1)}$, Michiko Morimoto ${ }^{1)}$ and Kazuhiro UGai ${ }^{1)}$ \\ 1) College of Nursing Art \& Science, University of Hyogo, ${ }^{2)}$ Oita University Faculty of Medicine School of Nursing
}

\begin{abstract}
Antiseptic hand rub is recommended in medical facilities. However, it is reported that staff frequently use less than the recommended quantity of alcohol-based hand rub when washing their hands. Furthermore, the hand rub is often not rubbed into the fingertips. The aim of this study was to verify whether there is a significant difference in the bacterial elimination effect according to the quantity of the hand rub used and also if the degree of thoroughness in rubbing the hand rub into the fingertips makes a significant difference or not. Participants were divided into fingertips rubbing groups and fingertips non-rubbing groups. Each group did a antiseptic hand rub using both the standard quantity $(3 \mathrm{~mL})$ and half the standard quantity $(1.5 \mathrm{~mL})$ of alcohol-based hand rub. The numbers of bacteria on the fingertips, fingers and palms were counted using the agar stamp method before and after the hand rub. In the fingertips non-rubbing group, the bacterial elimination rate ON the fingertips was significantly lower compared to the fingers and palms (both $3 \mathrm{~mL}$ and $1.5 \mathrm{~mL}$ $\mathrm{p}<0.001$ ). Also the $\log _{10}$ reduction of the fingertips was significantly lower in the non-rubbing group compared to the fingertips rubbing group $(3 \mathrm{~mL} \mathrm{p}<0.01,1.5 \mathrm{~mL} \mathrm{p}<0.001)$. Furthermore, in the fingertips non-rubbing group, the $\log _{10}$ reduction of the fingertips was significantly lower when $1.5 \mathrm{~mL}$ of hand rub was used than when $3 \mathrm{~mL}$ of hand rub was used $(\mathrm{p}<0.01)$. There was no difference in the bacterial elimination effect between the fingers and palms according to the quantity of hand rub or whether the hand rub was used on the fingertips. Furthermore it is necessary to recognize that the bacterial elimination effect will decrease if the quantity of hand rub used is less than half the recommended quantity.
\end{abstract}

Key words : antiseptic hand rub, hand hygiene, hand rub usage, bacterial elimination effect 